\title{
The State and the Development of Industrial Plantation Forest
}

\author{
Sudarmalik $^{1^{*}}$, Hariadi Kartodihardjo ${ }^{2}$, Sudarsono Soedomo ${ }^{2}$, Soeryo Adiwibowo ${ }^{3}$
}

\author{
${ }^{1}$ Graduate School of Bogor Agricultural University, Dramaga Main Road, Campus IPB Dramaga, Bogor, Indonesia 16680 \\ ${ }^{2}$ Department of Forest Management, Faculty of Forestry, Bogor Agricultural University, Academic Ring Road, Campus IPB \\ Dramaga, PO Box 168, Bogor, Indonesia 16680 \\ ${ }^{3}$ Departement of Communication Science and Community Development, Bogor Agricultural University, Academic Ring \\ Road, Campus IPB Dramaga, PO Box 168, Bogor, Indonesia 16680
}

Received July 21, 2014/Accepted November 24, 2014

\begin{abstract}
Development of industrial plantation forest is a form of principal-agent relationship, in which the Ministry of Forestry as a principal gives utilization permit to the entrepreneur as an agent, known as the Forest Timber Product Exploitation Permit on Planted Forest. This utilization permit obtained by the agents is operationally conducted by other parties through a cooperative agreement. The purpose of this study is to obtain an information regarding to the state position in the development of industrial plantation forest. The study was conducted in Riau Province, using the constructivist paradigm with phenomenological method. Data were obtained through in-depth interviews to selected informants. Data were also obtained from the review of documents to complement the interview. Data analysis was conducted using property rights and principal agent theories. The phenomenon of multi-chain transfer of the management rights of plantation forest that occoured in the observed companies showed that the state was unable to effectively control to the forest plantation. The study recommends that state should issue regulation to decrease or stops further transfer of the management rights of plantation forest. However, further study needs to overcome the existing over accumulation of plantation forest in a few hands.
\end{abstract}

Keywords: industrial plantation forest, property right, principal agent, the state position, authority

*Correspondence author, email: sudarmalik2008@gmail.com,tel.+62-81275352129

\section{Introduction}

The form authority of production forest utilization permit during the regional autonomy era in the context of the authority division is regulated in Government Regulation (Peraturan Pemerintah, PP) Number 25/2000 jo Government Regulation Number 38/2007 regarding to the division of powers between the government, the provincial government and district/city local government. The form of authority is also mentioned in the Government Regulation Number 34/2002 jo Government Regulation Number 7/2006 jo Government Regulation Number 3/2008, in which the Ministry of Forestry acts as the authority holder. During 2001-2003, the authority of granting production forest utilization permit was delegated to the local government (Ministry Regulation Number 10.1/2001). However, due to rampant corruption related to the local government permission granting, the authority was returned to the government in accordance to the Decree of the Minister of Forestry Number 32/2003. According to Dewi et al. (2010), the division of authority needs a clear responsibility so that public services can work well.

Forest production is a part of the state forest. The characteristics of the forest resources lead to the interstakeholders and inter-regional mutual dependence/ interdependence (Ostrom 2008). One of the efforts to suppress the interdependence is the arrangement of ownership rights as part of forest management rules. The transfer of authority does not eliminate the state function to conduct supervision. A state function as regulator including resource management has been defined by several experts, including Harold J. Laski and Robert M. Maclver (Budiardjo 2007). The principle of the existence state is the authority to regulate state. Through the concept of the welfare state, the state has a function to create prosperity through the fulfillment of the public interest (Ilmar 2012). In the management of forest resources, the state existence is to regulate the forest utilization, party distribution, and forest utilization rights.

Forest control by the state has put the state as the party that regulates the forest management (Kartodihardjo \& Jhamtani 2006). Forest control is intended as a state authority to regulate and manage all matters related to forest, forest area and forest products; regulate and establish the legal relationship between the people with forest or forest area and forest products, as well as regulate legal actions concerning forestry (Act Number 41/1999). One of the state regulation is implemented in the issuance of forest timber product exploitation permit. Permit granted during the 
decentralization era has put local governments in an enormous power (Zuhro 2013). However, the authority is still under the central government control. Although there is a local involvement in the permit issuance, the central government authority remains greater.

The study of government authority in the forest utilization has been done by several researchers, including Barr (1999), Kartodihardjo (1998), and Nugroho (2003). Research describe the government's authority in the utilization of natural forests and the relationship between the government and firm. Studies reviewed in this paper see the government's authority in the development of industrial plantation forests.

Based on the before description, the proposed research question is how to post the state/country in the industrial plantation forest development (Rawls 1995; Ali \& Lino 2013). The state position is intended as a role of the state in the implementation of industrial plantation forest development. The purpose of this study is to reveal the state position, in this case is the Ministry of Forestry, in the industrial plantation forest development.

\section{Methods}

This study used a qualitative approach with a constructivist paradigm (Denzim \& Lincoln 1997: Irawan 2007) which constructed the delegation of authority in the industrial plantation forest development. The construction of social process was conducted using phenomenology method (Moran 2000), a method that reveals the phenomenon by engaging informants as a primary source of information. The data collection process was conducted through in-depth interviews (Denzim \& Lincoln 1997), in which extract the understanding that illustrates the value, perception and attitude of informants toward a process that becomes a major goal in the interview. Data were also obtained from the analysis of laws/acts and regulations that regulate the industrial plantation forest (Hutan Tanaman Industri, HTI) development.

The field research was conducted in 2012 in Riau Province. The study site was selected based on the area of industrial plantation forest. According to the Ministry of Forestry, there are 1.6 million industrial plantation forest in Riau Province. In addition, there are also two large pulp and paper industries which have 3.9 million tons production capacity equivalent to $74 \%$ of the national pulp and paper productions (Forestry 2011). The key informants were actors involved directly or indirectly in the transfer of authority to grant permits on the development of industrial plantation forests. These informants were working in the government institutions (Ministry of Forestry, Riau Province Forestry Agency, and Pelalawan City Forestry Agency), forest entrepreneurs and forest contractors.

Documents being used as study materials were the legal documents of Forestry Law (Act Number 41/1999), PP Number 6/1999, PP Number 34/2002, PP Number 6/2007, and PP Number 3/2008; the Minister of Forestry Regulation that regulates operational cooperation namely Minister Regulation Number P.20/2005 jo P.37/2009 jo P.29/2012; and the documents of cooperation agreement in the implementation of operational cooperation; as well as the documents of industrial plantation forest development with the contractor. Legal document was analysis conducted through content analysis (Berger 1991; Khan et al. 2010). Phenomenological data was analysis included several stage process namaly; horizonalization, reduction and elimination; tektural description, structural description and determination of significance stages (Moustakas 1994; Kuswarno 2009).

\section{Results and Discussion}

In conducting the regulatory function of the statehood (Aji 2013), the state has the authority to control/manage forest resources for the greatest welfare of people. The controlling authority is held by the Ministry of Forestry as a state representative. This form of control is appeared in the forest administration, forest utilization, and management (Act Number 41/1999). Forest administration is the responsibility of government which is conducted through the implementation of: (a) forest planning, (b) forest management, (c) research and development, education and training and forestry extension, and d) supervision. Forest administration is jointly conducted between the government and local governments. Meanwhile, one of the forest management activities that are part of the government's responsibility is forest utilization.

Forest utilization through permission granted is a form of transfer of rights from the state/Minister of Forestry (principal) to the individual/cooperative/state/private who acts as agents. Principal-agent relationship is a relationship that one or more people as the trust grantors/principals affect others as partners who receive the trust to conduct several principal tasks by delegating decision-making authority to the appointed partners (Miller 2008). Meanwhile, according to Eggertsson (1990), the principal-agent relationship is a hierarchical relationship or exchange of property rights among individuals. This is a utilization permission of forest timber products (PP Number 34/2002 jo PP. 6/2007 jo PP. $3 / 2008$ ), which are all forms of businesses that utilize and commercialize forest timber products without harming the environment and do not reduce the forest principal function. The purpose of utilization permission granting is to increase the forest values, provide industrial raw materials and create employment/job (Srihadiono 2005). The improper/bad forest utilization is associated with high rates of deforestation (Amsberg 1998) and revenues (Soedomo 2013). Characteristics of forest timber product exploitation/ utilization permit which is regulated in the forestry regulations are shown in Table 1.

Delegation of authority and rights amendment Production forest is a state forest. State ownership is one of property right forms. Property right is the right of the individual, society, or nation over a resource (asset/ endowment) to manage, utilize, transfer, even impair it. These rights consist of the right to private property, state property, communal property, common property, and no owner/open access property (Ostrom 1990). The authority of the state in forest management rights is bound in a mutually attached rights in the bundle of rights (Ostrom \& Schlager 1992) which consists of access right, withdrawal right, management right, exclusion right and alienation right. Research about bundle of rights have done by Arsyad et al. (2007). 
Table 1 Characteristics of Forest Timber Product Exploitation Permit on Planted Forest (IUPHHK-HT)

\begin{tabular}{ll}
\hline \multicolumn{1}{c}{ Permit characteristics } & \multicolumn{1}{c}{ Explanation } \\
\hline IUPHHK-HT permit grantor & $\begin{array}{l}\text { Party who have authority to grant permission for IUPHHK-HT is the Minister of Forestry with the } \\
\text { recommendation from the governor and on the consideration from the regent/mayor. } \\
\text { Granting permission in the form of IUPHHK-HT is conducted through solicitation by businesses to the } \\
\text { Minister of Forestry. }\end{array}$ \\
$\begin{array}{ll}\text { Parties who can apply for permission to obtain IUPHHK-HT are individual, cooperative, local/state } \\
\text { enterprises (BUMD/BUMN), and private enterprise (BUMS). }\end{array}$ \\
$\begin{array}{l}\text { IUPHHK-HT concession period is } 60 \text { years and can be extended once for 35 years. } \\
\text { Transfer of rights }\end{array}$ & Transfer of rights to exploit forest can be conducted after permit grantor issues written approval. \\
\hline
\end{tabular}

Delegation of authority of production forest utilization implicates to the change of rights attached to the state and business actors. This delegation does not change the ownership of forest, but it only bestows/delegates the state rights according to the bundle of rights. The forest state property right is an institutional set that regulates the occuring interactions between stakeholder in the production forest utilization (Behera \& Engel 2006). Delegation of authority from the state to the business actors to develop industrial plantation forest is conducted through three stage relationships namely relationship between the Ministry of Forestry with IUPHHK-HT holders (a principal-agent), the relationship between IUPHHK-HT holder with operational cooperation (KSO) or IUPHHK-HT holder with contractor, and the relationship between the operational cooperation practitioners with contractor of industrial plantation forest development. The principal-agent relationship in the industrial plantation forest development has been studied by Nugroho (2003) in natural forest management right (Hak Pengusahaan Hutan, HPH). Principal-agent relationship in the utilization of natural forest was conducted through three stages involving government, forest utilization permission holders, and contractors. Principal-agent relationship occurs in the industrial plantation forest development which is related to the permission granting process of IUPHHK-HT, where the principal does not have perfect information on the existence of forest resources and IUPHHK-HT holders.

\section{Delegation of the state authority to IUPHHK-HT holder}

Delegation of the state authority to IUPHHK-HT holder in the form of permission is known as Timber Forest ProductPlan Forest Utilization Permit (Izin Usaha Pemanfaatan Hasil Hutan Kayu Hutan Tanaman, IUPHHK-HT). This permission is given through a request and issued subsequrent IUPHHK-HT assessment letter containing the provisions, rights, obligations and prohibitions of IUPHHK-HT holder. The utilization permit is a valid legal document or permissibility of a person. This permit to conduct certain business or activity. The permission consists of permit, dispensation, license, concession, and recommendation (Dewa 2011).

This delegation of authority is to transfer rights of access, withdraw, management, and exclusion from the Ministry of Forestry to IUPHHK-HT holder (Table 2). The process of authority delegation is not followed by the transferring right to trade (alienation right) the forest area. The right that is held by IUPHHK-HT holder is the access right to utilize forest resources to develop industrial plantation forest. Although this right has been given to IUPHHK-HT holders, local communities also still have the access right to utilize non-subtractive forest products. The arrangement of access right is determined by the IUPHHK-HT holder. Meanwhile, the right to utilize forest products in the region as well as the right to delegate others to conduct forest products utilization, are authorized to IUPHHK-HT holder. Thus, the delegation of this authority entitles the IUPHHK-HT holder to conduct forest products utilization and regulate the access of others.

Delegation of authority put the forest area as a state asset, but the planted trees as permit holder asset. Separating of forest asset between state and permit holder is contained in the IUPHHK-HT Decree. The IUPHHK-HT Decree establishes IUPHHK-HT holder as a party who is prohibited to perform a contract or hand over all or some part of the business activities to other parties without the approval of the minister of forestry. The prohibition is a form of state supervision to the forest area. According to Sukarmi (2011), an agreement or contract in the business implementation can lead to monopoly. The monopoly takes place through the acquisition of shares by a large company. Symptoms mastery IUPHHK-HT is a phenomenon that occurs in the development of plantation forests. The possibility of monopoly occurence is the state responsibility, thus the state must conduct a supervision in order to improve the welfare.

The state function after transferring authority is to supervise the process of industrial plantation forest development and the state revenues (Handadhari et al. 2005). The state revenue from the reforestation fund (Dana Reboisasi, DR) and the provision of forest resources (Provisi Sumber Daya Hutan, PSDH) is a tool to achieve the state welfare goal. Reforestation funds obtained from the clearing of natural forests into industrial plantations forest, whereas provision of forest resources comes from plantations. The supervision is conducted by the technical implementation unit (Unit Pelaksana Teknis, UPT) of the Ministry of Forestry which is located in the regional district. This technical implementation unit namely the Center for Forest Area Consolidation (Balai Pemantapan Kawasan Hutan, BPKH) and the Center for Supervision of Production Forest Exploitation (Balai Pemantauan Pemanfaatan Hutan Produksi, BP2HP). The BPKH is the technical 
Table 2 Changes in Bundle of Right after IUPHHK-HT issuance by Ministry of Foresty to IUPHHK-HT holders

\begin{tabular}{lccccc}
\hline \multirow{2}{*}{ Stakeholder } & \multicolumn{5}{c}{ Bundle of rights } \\
\cline { 2 - 6 } & $\begin{array}{l}\text { Access } \\
\text { right }^{1)}\end{array}$ & $\begin{array}{l}\text { Withdrawal } \\
\text { right }^{2}\end{array}$ & $\begin{array}{l}\text { Management } \\
\text { right }^{3)}\end{array}$ & $\begin{array}{l}\text { Exclusion } \\
\text { right }^{4}\end{array}$ & $\begin{array}{l}\text { Alienation } \\
\text { right }^{5}\end{array}$ \\
\hline Ministry of Forestry & $\sqrt{ }$ & $\sqrt{ }$ & $\sqrt{ }$ & $\sqrt{ }$ \\
IUPHHK-HT holder & $\sqrt{ }$ & $\sqrt{ }$ & $\sqrt{ }$ & $\sqrt{ }$ & - \\
Operational cooperation practitioner & $\sqrt{ }$ & $\sqrt{ }$ & $\sqrt{ }$ & - & - \\
Contractor & $\sqrt{ }$ & $\sqrt{ }$ & & & - \\
\hline
\end{tabular}

\begin{tabular}{l} 
Remarks : \\
$\sqrt{ }=$ Reserve the right \\
\hline $1_{\text {Bundle of right consists of: }}$ \\
1) The right to physically enter the forest and enjoy non-subtractive benefits \\
2) The right to receive the benefits of forest products, such as utilizing forest timber products or non-timber \\
4) The right to regulate internal utilization patterns and resources transformation through improvements \\
The right to determine who has an access rights and how these rights are allowed to be transferred
\end{tabular}

implementation unit of the Directorate General of Forest Planning. Whereas, The BKPH as a technical implementation unit of Directorate General of Forestry Enterprises, Ministry of Forestry. The role of the BPKH in the industrial plantation forest development is to provide recommendations on the function and status of the forest area that will be proposed into industrial plantation forest. Meanwhile, BP2HP has a role in monitoring forest products exploited from the production forest.

The supervision which is conducted by the Ministry of Forestry after transferring authority only includes the supervision of state revenue obtained in the industrial plantation forest development. This form of supervision also involves Provincial and District Forestry Agencies. The involvement of local government in the supervision is solely an administrative manner (Ekawati 2010). Monitoring of forest condition is in a mere administrative supervision as if it is not conducted by the government or local government.

The principal-agent relationship in the delegation of authority on the production forest utilization has some impacts associated with the transfer of rights, asymmetric information and transaction costs. The impact of the principal-agent relationship can be reduced by selecting the right agent. In the development of industrial plantation forests, this impact caused by the transfer of rights. Transfer of rights that occurs is a transfer of access right, withdrawal right and management right to IUPHHK-HT holder. This transfer is not free from other party claims. Several cases in the industrial plantation forest development in Riau reveal a conflict caused by unclear status of forest area. Negotiation process is required (Dhiaulhaq et al. 2014) to resolve these claims and it is a social issue that becomes the responsibility of IUPHHK-HT holder. Claims of local community over IUPHHK-HT region is generating cost for IUPHHK-HT holder. This cost appears to resolve the conflict.

The impact of principal-agent relationship in the industrial plantation forest development is also derived from the presence of asymmetric information that is caused by principal (goverment) ignorance regarding to the forest details. Information about the ecology and social condition of the forest area is owned by the agen (IUPHHK-HT holder).
In addition, the principal-agent relationship in the industrial plantation forest development also contributes to the high transaction costs in the process of obtaining IUPHHK-HT permit. The process of obtaining IUPHHK-HT permit involves central and local agencies. These process followed by the lack of process transparency can lead to the high transaction costs (Williamson 2008). The high transaction costs due to the long process to obtaining of IUPHHK-HT permit.

\section{Delegation of authority of IUPHHK-HT holder to operational cooperation practitioners}

Delegation of operational authority to the industrial plantation forest development by IUPHHK-HT holder to contractors or operational cooperation practitioners is conducted through an operational cooperation (KSO). This delegation agreement by IUPHHK-HT holder who has the financial ability to implement industrial plantation forest development activities. While the delegation of authority through the operational cooperation is conducted by IUPHHK-HT holder who does not have the financial ability. The characteristics of IUPHHK-HT holder is correlated with IUPHHK-HT issuance that involves rent-seekers. The rentseeker is pursuing profit by exploiting the potential of natural timbers from forest areas. Typology of IUPHHK-HT holder in the industrial plantation forest development can be divided into three type, namely (1) IUPHHK-HT holder who is capable of conducting independent industrial plantation forest development, (2) IUPHHK-HT holder who does not have the ability to develop industrial plantation forest and then to perform operational cooperation, and (3) IUPHHKHT holder who does not have the financial ability and then selling IUPHHK-HT to big entrepreneur/businessman. Typology of IUPHHK-HT holder is correlated with the permission granting process by the government (Oliveira 2008).

Delegation of authority by IUPHHK-HT holder through the operational cooperation is based on the Minister of Forestry Regulation Number P.20/2005 jo P.37/2009 jo P.29/2012. This delegation is allegedly caused by entrepreneurs pressure to legalize operational cooperation 
conducted by IUPHHK-HT holder. The case of the pressure on the policy process has been studied by Rumboko et al. (2013). This pressure changes the contain of Forestry Ministry Regulation. The ministerial regulation changes are simply changing the scope of the implementation of operational cooperation. Meanwhile, the operational cooperation agreement contains matters related to the responsibility agreement of IUPHHK-HT holder and operational cooperation practitioners. Another agreement to control sale of forest products to the pulp and paper industry owners, the duration of implementation of operational cooperation and the selling price agreement of timber obtained from industrial plantation forest. KSO is a form of the distribution of responsibilities among parties in the industrial plantation forest development. The distribution of these responsibilities can be described as follows, IUPHHKHT holder has the responsibility to make the forest plan. That resposibility includes to set up of IUPHHK-HT concession boundaries, the preparation of the General Work Plan (Rencana Karya Umum, RKU) within 10 years period, macro and micro delineation, Comprehensive Periodic Forest Inventory (Inventarisasi Hutan Menyeluruh Berkala, IHMB), and Annual Work Plan (Rencana Karya Tahunan, RKT). Macro and micro delinneation is a policy to regulate the development of industrial plantation forest from natural forest. KSO practitioners are responsible of the capital (as IUPHHK-HT holder with large capital). KSO practioners as a party that is entered into agreements with IUPHHK-HTholders. Contractor as a party that is entered into the agreement to establish industrial plantation forest. The contractor is responsible to establish as determined by the operational cooperation practitioners. Delegation of authority by IUPHHK-HT holder to cooperation practitioners or contractor could result in the change of rights as listed in Table 2. The right held by the operational cooperation practitioners or contractor is access rights, withdrawal rights, and the management rights, which conducts industrial plantation forest development. Whereas, the exclusion rights remain as IUPHHK-HT holder rights.

\section{Delegation of authority to the contractor}

Three-level relationships (Nugroho 2003) in the development of industrial plantation forest are principalagent relationships between IUPHHK-HT stakeholders or operational cooperation and the contractor. Contractor consists of nursery contractor, land preparation, and planting contractor, as well as logging and transporting contractors. Authority possessed by these contractors is only to conduct work which is in accordance to the agreements. In these three-level relationships, the transfer of rights from IUPHHK-HT holder or operational cooperation to the contractor is the access rights, withdrawal rights, and the management rights. The transfer of authority to the contractor does not transfer liability of IUPHHK-HT holder. Agreement between the government and IUPHHK-HT holder remains IUPHHK-HT holder's responsibility.

The state position Principal-agent relationship (Jensen \& Meckling 1976) in the development of industrial plantation forests is a form of temporary transfer of rights. The delegation of right requires supervision to maintain the status of bestowed forest. Supervision is conducted by the Ministry of Forestry and Provincial and District Forestry Agency. This supervision is important to maintain supply raw material from industrial plantation forest to the pulp and paper industries, because these industries have bright economic prospects (Alfarisi 2009).

The authority in the development of industrial plantation forest has undergone a change of property right. IUPHHKHT holder delegates some parts of operational activities of industrial plantation forest development to the operational cooperation practitioners or contractor. Delegation to the contractor affects to the inability of the Ministry of Forestry to conduct a direct supervision. This delegation is caused by high transaction costs abtain IUPHHK-HT permit and to establish industrial plantation forest. According to Kim and Mahoney (2005), property right is related to the structure of incentives provided. Delegation of authority with three level relationships become disincentives to development industrial plantation forest. The form of property right with the state forest status and the withdrawal right granted by the state has led to the higher transaction costs. The occurence of these transaction costs acts as a disincentive to the development of industrial plantation forest.

Although government incentives through equity participation and indirect incentives such as Land Conversion Permit (Izin Pemanfaatan Kayu, IPK) have been given, it could not drive the behavior of IUPHHK-HT holders to comply with the prohibition of the transfer of development activities to the other parties. IUPHHK-HT holders more instresting to get revenue from land conversion permint. IPK is a license to carry out logging of natural forests. This permit has an impact on the coverage of surveillance conducted by the ministry of forestry which failed to reach the operational cooperation practitioners or contractor. The ministry of forestry can not directly surveillance the operational cooperations practitioners and contractor. Surveillance of the ministry of forestry only to the IUPHHK-HT holder

The delegation of authority by IUPHHK-HT holder to the operational cooperation practitioners or the contractors is due to the non-compliance of IUPHHK-HT holder. The noncompliance to the rules stated by the ministry of forestry in IUPHHK-HT decree. The statement of the IUPHHK-HT decree declare that operational cooperational must be approved by ministry of forestry. However, no operational cooperation practitioners approved by ministry of forestry.

The incompetence of IUPHHK-HT holder to operate in the development of industrial plantation forest becomes the cause of the operational cooperation. Ministry of Forestry as the principal does not understand the agent's capability, both technical and financial capabilities. This is due to the permission system which is only observed from the administrative requirements (Muallidin 2012). Ministry of forestry remains unknows in details information regarding to the applicant conditions. Consequently, delegation of authority granted to IUPHHK-HT holder does not comply with the requirements outlined by the Ministry of Forestry.

The authority delegation of IUPHHK-HT holder to the operational cooperation practitioners and contractor can lead 
to the failure. This failure is achieving industrial plantation forest development to reduce poverty (Rumboko 2013). Delegation is also causing an ineffective supervision conducted by the ministry of forestry. Although the ministry of forestry has the technical implementation unit (Unit Pelaksana Teknis, UPT) in the area consisting BPKH and BP2HP, supervision is only conducted in administrative manner. Similarly, the provincial forest agency and district forest agency are only conducting administrative supervision. In the long term, the delegation of authority which involves the change of rights and inefficient principalagent relationship can cause a decrease in soil fertility conditions of industrial plantation forest (Wasis 2004). The development of industrial plantation forest enters three rotations and subsequently experiences the decreased in financial advisability (Sudarmalik 2008). Rotations is the time it takes from planting to harvest. Each rotation takes 5 years.

Delegation of authority followed by principal-agent relationship between IUPHHK-HT shareholders with operational cooperation practitioners and operational cooperation practitioners with the contractor occurs as if there is no one taking responsibility of forest areas. Consequently, there is no guarantee over the sustainability of industrial plantation forest development.

\section{Conclusion}

Delegation of authority in industrial plantation forest development through the provision of utilization rights with the principal-agent relationship that exists today does not guarantee the preservation of forest land. The created principal-agent relationship causing the state supervision does not reach activity practitioners in the field.

\section{Recommendation}

It is necessary to conduct a strict supervision by the Ministry of Forestry toward the development of industrial plantation forest that delegates the development authority of industrial plantation forest through operational cooperation.

\section{References}

Aji G. 2013. Imperialisme kehutanan dan konflik penguasaan hutan di Indonesia. Jurnal Ilmu Pemerintahan 41:21-32.

Ali F, Lino J. 2013. Antara Pasar dan Politik, BUMN di Bawah Dahlan Iskan. Jakarta. PT. Gramedia.

Alfarisi DA. 2009. Analisa struktur dan kinerja industri pulp dan kertas Indonesia. Jurnal Persaingan Usaha 1:61-92

Alston L, Muller B. 2008. Property Right and The State. In: Menard C, Shirley MM, editors. Handbook of New Institutional Economics. Heidenberg: Springer-Verlag Berlin Heidenberg. 573-590

Amsberg J. 1998. Economic parameters of deforestation. The World Bank Economic Review 12(1):133-153. http://dx.doi.org/10.1093/wber/12.1.133.
Arsyad A, Kusumastanto, Saefudin A, Soetarto E. 2007. Karakteristik dan tipologi hak-hak kepemilikan dalam perikanan artisanal. Buletin PSP 16(2): 35-50

Barr C. 1999. Discipline and accumulate state practice and elite consolidation in Indonesia Timber sector 1976-1998 [thesis]. New York: Cornell University.

Behera B, Engel S. 2006. Institutional analysis of evolution of joint forest management in India: A new institutional economic approach. Journal Policy and Economics 8:350-362. http://dx.doi.org/10.1016/j.forpol.2005. 08.006 .

Berger A. 1991. Media Analysis Techniques. Beverly Hills: Sage Publications.

Budiardjo M. 2007. Ilmu Politik. Jakarta: Universitas Indonesia Press.

Dewa J. 2011. Hukum Administrasi Negara, dalam PerspektifPelayanan Publik. Kendari: Unhalu Press.

Dewi IN, Rizal H, Kusumedi P. 2010. Study of the implementation of protection forest management rules: case study in Pangkep and Maros Regencies, South Sulawesi Province. Jurnal Analisis Kebijakan Kehutanan 7(3):195-209.

Denzim K, Lincoln Y. 1997. Handbook of Qualitative Research. Jakarta: Pustaka Pelajar.

Dhiaulhaq A et al. 2014. Transforming conflict in plantation through mediation: lesson experiences from Sumatera, Indonesia. Forest Policy and Economics 41:22-30. http://dx.doi.org/10.1016/j.forpol. 2014.01.003.

Eggertsson T. 1990. Economics Behavior and Institutions. USA: Cambridge University Press.

Ekawati S. 2010. The study of working relationship between institution in the management of protected forest in the era of autonomy. Jurnal Analisis Kebijakan Kehutanan 7(3):211-225.

Gibson CC, Lehoucq FE, William JT. 2002. Does privatization protect natural resources? Property rights and forest in Guatemala. Social Sciences Quarterly 83(1):206-225. http://dx.doi.org/10.1111/1540-6237. 00079 .

Gunawan K. 2004. The Politic of The Indonesian Rain Forest, A Rise of Forest Conflict in East Kalimantan During Indonesia's Early Stage of Democratisation. Gottingen: Cuvillier Verlag.

Handadhari T, Sumitro A, Warsito S, Widodo S. 2005. Analisis pungutan rente ekonomi kayu bulat hutan tanaman industri di Indonesia. Jurnal Penelitian Sosial dan Ekonomi Kehutanan 2(2):137-148.

Ilmar A. 2012. Hak Menguasai Negara dalam Privatisasi 


\section{BUMN. Jakarta: Kencana Prenada Media Group}

Irawan P. 2007. Penelitian Kualitatif dan Kuantitatif untuk Ilmu-Ilmu Sosial. Jakarta: Fisip UI Press.

Jensen MC, Meckling WH. 1976. Theory of the firm: managerial behavior, agency costs, and ownership structure. Journal of Financial Economics 3(4):305-360. http://dx.doi.org/10.1016/0304-405X(76) 90026-X.

Kartodihardjo H. 1998. Peningkatan kinerja pengusahaan hutan alam produksi melalui kebijaksanaan penataan institusi [dissertation]. Bogor: Bogor Agricultural University.

Kartodihardjo H, Jhamtani H. 2006. Politik Lingkungan dan Kekuasaan di Indonesia. Jakarta: Equinox Publishing

Kementerian Kehutanan. 2011. Statistik Kehutanan 2011. Jakarta: Kementerian Kehutanan.

Khan A, Kartodihardjo H, Soedomo S, Darusman D. 2010. Forestry utilization policy: a discourse analysis. Jurnal Manajemen Hutan Tropika 16(2):101-111.

Kim J, Mahoney J. 2005. Property right theory, transaction costs theory and agency theory: An organizational economics approach to strategic management. Managerial and Decision Economics 26:223-242. http://dx.doi.org/10.1002/mde.1218.

Kuswara E. 2009. Fenomenologi: Konsepsi, Pedoman dan Contoh Penelitiannya. Bandung: Widya Padjajaran.

Laski JH. 1947. The State in Theory and Practice. New York: The Viking Press.

Libecap GD. 2009. The tragedy of the commons: Property right and markets solutions to resource and environmental problem. The Australian Journal of Agricultural and Resource Economics 53:129-144. http://dx.doi.org/10.1111/j.1467-8489.2007.00425.x.

Maclver MR. 1926. The Modern State. London: Oxford University Press.

Media Data Riset. 2010. Progres Pasar Industri Pulp dan Kertas Indonesia, 2010. Jakarta: Media Data Riset.

Menard C. 2008. A new institutional approach to organization. In: Menard C, Shirley MM, editors. Handbook of New Institutional Economics. Berlin: Springer-Verlag. http://dx.doi.org/10.1007/978-3-54069305-5_13.

Miller G. 2008. Solution to principal-agent problem in firm. In: Menarrd C, Shirley MM, editors. Handbook of New Institutional Economics. Berlin: Springer-Verlag. http://dx.doi.org/10.1007/978-3-540-69305-5_15.

Moran D. 2000. Introduction to Phenomenology.
Routledge 11 New Fetter Lane, London and 29 west 35 th street New York

Moustakas CE. 1994. Phenomenological Research Methods. USA: Sage Publications.

Muallidin I. 2012. Implementasi reformasi organisasi perizinan di Dinas Perizinan Kota Yogyakarta. Jurnal Ilmu Sosial dan Ilmu Politik 15(3):246-255.

Nugroho, B. 2003. Kajian institusi pelibatan usaha kecilmenengah industri pemanenan hutan untuk mendukung pengelolaan hutan lestari [dissertation]. Bogor: Bogor Agricultural University.

Nugroho, B. 2011. Land rights of community forest plantation policy: analysis from an institutional perspective. Jurnal Manajamen Hutan Tropika 17(3):111-118.

Oliveira JA. 2008. Property right, and conflict and deforestation in the eastern Amazon. Journal Forest Policy and Economics 10:303-315. http://dx.doi.org/10. 1016/j.forpol.2007.11.008.

Ostrom E. 1990. Governing the Commons: The Evolution of Institutions for Collective Actions. Massachusetts: Cambridge University Press.

Ostrom E. 2008. Institutions and the environment. Journal Compilation of Institute of Economic Affair 24-31. http://dx.doi.org/10.1017/CBO9780511807763.

Rawls J. 1995. A Theory of Justice. Massachusetts: Harvard University Press.

Rumboko LR, Race HD, Curtis AL. 2013. Policy under pressure: policy analysis of community-based forest management in Indonesia. International Forestry Review 15(1):1-8.

Rumboko LR, Race HD, Curtis AL. 2013. Optimizing community-based forest management policy in Indonesia, a critical review. Jurnal Ilmu Sosial dan Ilmu Politik 16(3): 250-272.

Schlager E, Ostrom E. 1992. Property-right regimes and natural resources: a conceptual analysis. Journal Land economics 68(3):249-262. http://dx.doi.org/10.2307/ 3146375 .

Soedomo S. 2013. Double devidend from tariff differentiation of reforestation fund. Jurnal Manajemen Hutan Tropika 19(2):163-167. http://dx.doi.org/10. 7226/jtfm.19.2.163.

Srihadiono U. 2005. Hutan Tanaman Industri: Skenario Masa Depan Indonesia. Palembang-Banten: PT Musi Hutan Persada dan Wana Aksara.

Sukarmi. 2011. Pembuktian kartel dalam hukum persaingan usaha. Jurnal Persaingan Usaha 6:119-149. 
Sudarmalik. 2008. Analisis kelayakan pembangunan hutan tanaman industri (HTI) pada berbagai rotasi tebang. In: Prosiding Seminar Hasil Penelitian; Riau, June 15, 2008.

Wasis B. 2002. Karakteristik kesuburan tanah hutan tanaman industri [dissertation]. Bogor: Bogor Agricultural University.
Williamson O. 2008. Transaction Cost Economics. In: Menard C, Shirley MM, editors. Handbook of New Institutional Economics. Berlin: Springer-Verlag. http://dx.doi.org/10.1007/978-3-540-69305-5_4.

Zuhro S. 2013. Politik pertanahan: jalan tak ada ujung. Jurnal Ilmu Pemerintahan: Politik Agraria dan Konflik Agraria 41: 1-20. 